Review

\title{
UNRAVELING THE SIGNALING AND SIGNAL TRANSDUCTION MECHANISMS CONTROLLING ARBUSCULAR MYCORRHIZA DEVELOPMENT
}

\author{
Marcio Rodrigues Lambais \\ USP/ESALQ - Depto. de Ciência do Solo, C.P. 09 - 13418-900 - Piracicaba, SP - Brasil. \\ e-mail <mlambais@esalq.usp.br>
}

\begin{abstract}
Arbuscular mycorrhiza (AM) are the most widespread symbiotic associations between plant roots and soil fungi. AM can contribute to increasing the survival and fitness of plants to limiting environments mostly due to their ability in improving nutrient uptake from the soil solution. Despite their ecological significance, the mechanisms controlling AM development and functioning are largely unknown. The obligate mutualistic nature of the arbuscular mycorrhizal fungi (AMF) has hampered the advances on the understanding and application of the symbiosis. Significant alterations in the genetic programs of both symbionts are required for the successful establishment of an AM, and complex signaling and signal transduction mechanisms are likely involved. The analyses of legume mutants affected in the development of nitrogen fixing nodules and AM suggest that part of the signal transduction pathways involved in the regulation of both symbioses are conserved. Even though the use of genomics of model plants has helped to advance our understanding of the regulatory mechanisms in AM, identifying the signal molecules involved in plant-AMF communication and determining their transduction pathways is still essential for its biotechnological application in agriculture.
\end{abstract}

Key words: DMI gene, symbiosis, branching factor, receptor, calcium spiking

\section{DESENREDANDO OS MECANISMOS DE SINALIZAÇÃO E TRANSDUÇÃO DE SINAIS QUE CONTROLAM O DESENVOLVIMENTO DE MICORRIZAS ARBUSCULARES}

\begin{abstract}
RESUMO: As micorrizas arbusculares (MAs) são as associações simbióticas entre raízes de plantas e fungos mais comuns na natureza. Elas podem contribuir para o aumento da sobrevivência e adaptação das plantas a ambientes limitantes, principalmente devido a sua maior capacidade em absorver nutrientes da solução do solo. Apesar de sua importância ecológica, os mecanismos que controlam o desenvolvimento e fisiologia das MAs são pouco conhecidos. A natureza mutualística obrigatória dos fungos micorrízicos arbusculares (FMAs) tem limitado os avanços na compreensão e aplicação da simbiose. Alterações significativas nos programas genéticos de ambos simbiontes são necessárias para o estabelecimento de MAs, e mecanismos complexos de sinalização e transdução de sinais estão provavelmente envolvidos. A análise de mutantes de leguminosas defectivos no desenvolvimento de nódulos fixadores de nitrogênio e MAs sugere que uma parte das vias de transdução de sinais envolvidas na regulação dessas simbioses é conservada. Muito embora o uso da genômica de plantas modelos tenha contribuído para o avanço na compreensão dos mecanismos que regulam MAs, a identificação de moléculas sinais envolvidas na comunicação planta-FMA, e a determinação de suas vias de transdução, é essencial para aplicação da simbiose na agricultura.

Palavras-chave: gene DMI, simbiose, fator de ramificação, receptor, oscilação de cálcio
\end{abstract}

\section{INTRODUCTION}

Arbuscular mycorrhizal fungi (AMF) belong to Glomeromycota, and can form mutulistic symbioses, named arbuscular mycorrhiza (AM), with more than $80 \%$ of the higher plants. It has been postulated that these fungi played a key role in the land colonization by primitive plants, since their root systems were not well developed for extracting nutrients and water from the soil. In this context, the symbioses formed between AMF and plants would help both the plant, in the uptake of nutrients from the soil solution, especially those of low mobility, and the fungi, in the acquisition of carbohydrates synthesized by the plant photosynthetic process. The ecological importance of $\mathrm{AM}$ is unquestionable and AMF certainly have con- 
tributed to structuring of plant communities in different ecosystems.

The long co-evolution period has rendered AMF so dependent on the symbioses that they became obligate symbionts, i.e., they are unable to grow in the absence of living host roots. AMF in general are able to colonize a wide range of plants to different degrees. AM development normally begins with the germination of an asexual fungal spore in the soil. This process is not dependent on the presence of the host plant, since spore germination can occur in water. Upon the perception of signal molecules synthesized by the plant, the fungal hypha start to profusely branch and ultimately differentiate into appressoria on the root surface. The penetration may occur between or through the epidermal cells and either intercellular or intracellular fungal growth is observed in the cortical tissue. In the inner cortex, intracellular hypha differentiate into highly branched structures, named arbuscules, which are involved in the bi-directional transfer of nutrients between plant and fungus. The arbuscules are surrounded by a symbiotic plasma membrane and interfacial symbiotic matrixes of plant origin, forming the symbiosome. The arbuscule lifespan is between four and 10 days, and they are completely degraded after collapsing.

Even though several aspects of the chemical communication during the pre-symbiotic stage, intracellular accommodation and intraradical colonization processes have been elucidated in the last few years, the molecular mechanisms regulating AM development and functioning are largely unknown. The understanding of AM development has benefited enormously in the last decade from the use of genomics techniques and genetics of model plants, especially the legumes Medicago truncatula and Lotus japonicus. In addition, observations that some non-nodulating legume mutants are also unable to form AM, or have AM development impaired at different stages, have contribute to partially elucidate common signal transduction pathways regulating both symbioses. This review discuss some of the most recent advances in the research on chemical signaling and signal transduction during the development of AM, and the perspectives of novel experimental work that can be performed to understand the genetic programs used to control the symbiosis.

\section{Chemical communication during the pre-symbiotic stage}

It has been described since the early seventies that plants produce chemical factors affecting the growth of AMF (Siqueira et al., 1985; Mosse, 1973). The so called "branching factors" (BFs) have been hypothesized to be plant signal molecules essential for hypha morphogenesis and differentiation (Giovannetti et al., 1994). Plant flavonoids are involved in the early chemical signaling during legume-rhizobia symbioses and have been shown to be major factors in root exudates of P-deficient plants affecting AMF spore germination and growth (Nair et al., 1991). For that reason, these molecules were considered possible signal factors necessary for fungal differentiation and root colonization (Kape et al., 1993; Siqueira et al., 1991a). Even though flavonoids have differential effects on spore germination, germ tube growth and root colonization (Kape et al., 1993; Siqueira et al., 1991b), using maize mutants defective in the synthesis of chalcone synthase, it has been demonstrated that they are not essential for AM development (Becard et al., 1995). Later, hyphal branching in Glomus mosseae was shown to be dependent on a low molecular weight compound of less than 500 Da present in the exudates of growing roots of Ocimum basilicum (Giovannetti et al., 1996).

The effects of these BFs on AMF were determined after Nagahashi and Douds developed a bioassay for studying the interaction of root exudates and germinating spores of Gigaspora margarita (Nagahashi \& Douds, 1999). Using this bioassay, it has been shown that a BF is present in root exudates of all host plants tested but not in the root exudates of non-host plants (Nagahashi \& Douds, 2000; Buee et al., 2000). In addition, the root exudates of plants grown under low $\mathrm{P}$ conditions are more active in inducing hyphal branching than root exudates of plants gown under high P conditions (Nagahashi \& Douds, 2000), suggesting that the synthesis rate or activity of the BF under low $\mathrm{P}$ is higher than at high $\mathrm{P}$ conditions (Nair et al., 1991).

The branching-inducing activity was partitioned into ethyl acetate from aqueous root exudates and was shown to be retained in a C18 reverse-phase resin, indicating that the BF is lipophilic (Nagahashi \& Douds, 2000). However the low concentration of the $\mathrm{BF}$ in root exudates and relative instability of the molecule have hampered its purification, until Akiyama and collaborators isolated, from the root exudates of Lotus japonicus grown hydroponically under low $\mathrm{P}$ conditions, a lipophilic compound which could induce branching of G. margarita hypha, using a paper disc diffusion method (Akiyama et al., 2005). This molecule was extracted from aqueous root exudates using ethyl acetate, and shown to be active at concentrations as low as $1.9 \mu \mathrm{g}$ per disk. It was further shown that the BF was an ethyl acetate-neutral compound. The BF exudated by the roots of $L$. japonicus was concentrated by circulating the hydroponic solution through an active charcoal cartridge and eluting the bound com- 
pound with acetone. After further chromatographic purification steps, the purified BF was subject to spectroscopic analyses. The data strongly suggested that the $\mathrm{BF}$ is structurally closely related to strigolactones, a group of sesquiterpene lactones that induce seed germination of the parasitic plants Striga and Orobanche. Chemical synthesis helped to identify the BF as a 5deoxy-strigol. Using the paper disk bioassay, Akiyama et al. (2005) showed that 5-deoxy-strigol, sorgolactone, strigol and GR24 (synthetic analogue) induce hyphal branching of G. margarita at very low concentrations. Strigolactones are sesquiterpene lactones produced by a wide number of mono and dicotyledonous plant species concentrations as low as $10^{-10} \mathrm{M}$ (Humphrey \& Beale, 2006; Matusova et al., 2005). The list of plant species which can synthesize strigolactones includes Arabidopsis thaliana, which is not able to form AM. However, the stimulation of Orobanche aegyptiaca seeds germination was lower in the presence of $A$. thaliana, in comparison to tobacco and carrot, suggesting that $A$. thaliana exudates contain lower amounts of the signal molecule, or that its activity is lower in comparison to the activities of the molecules synthesized by the other plant species (Westwood, 2000). In addition, the production of strigolactones by red clover is stimulated by low $\mathrm{P}$ conditions (Yoneyama et al., 2001), which are also favorable to AM development. Under field conditions, soil inoculation with Glomus clarum and G. margarita suppresses Striga emergence by $30 \%$ in maize and more than $50 \%$ in sorghum cultures (Lendzemo et al., 2005). These data suggest that the exudation of strigolactones in mycorrhizal roots is higher than in non-mycorrhizal roots, inducing a suicidal germination of Striga seeds at distances from the host plant that do not allow colonization by the parasitic plant. However, whether the increased secretion of strigolactones is due to a high $\mathrm{P}$ concentration in mycorrhizal roots is unknown.

The metabolic pathway leading to the biosynthesis of strigolactones is not completely understood. Matusova et al. (2005) demonstrated that (+)-strigol is derived from the carotenoid biosynthetic pathway, using inhibitors of carotenoid biosynthesis and carotenoid metabolism-impaired maize mutants. Based on experiments using inhibitors of the early stages of terpene biosynthesis, it has been suggested that strigolactones are partially synthesized in the plastids and translocated to the cytosol where their biosynthesis is completed (Humphrey \& Beale, 2006). Even though strigolactones may induce AMF hypha branching, the essentiality of 5-deoxy-strigol for AM formation remains to be determined. Another question that remains to be elucidated is whether there are other plant sig- nals involved in the pre-symbiotic communication between plant and AMF. Available information suggests the existence of different plant molecules that may be perceived by AMF. The use of BFs biosynthesis-impaired plant mutants will certainly contribute to understanding their biosynthetic pathway and biological roles during AM development. The identification and characterization of plant mutants unable to develop AM may also contribute to the identification of additional plant signal molecules involved in the early communication between the symbionts.

Other than the chemical nature of at least one plant signal molecule putatively involved in AM development, almost nothing is known hitherto on the signal molecules synthesized by the fungus, i.e., Mycfactors. Different lines of evidence suggest that active fungal molecules induce the expression of several plant genes in the early stages of AM development, such as those encoding defense-related proteins, early nodulins, and proteins with predicted functions in signal transduction (Weidmann et al., 2004; Chabaud et al., 2002; Lambais \& Mehdy, 1995).

Chabaud et al. (2002) developed an in vitro system to study the early stages of AM development using Agrobaterium rhizogenes-transformed $M$. truncatula roots containing a gusA fusion under the control of the MtENOD11 promoter, and showed that gene transcription is activated in epidermal and cortical cells infected with Gigaspora rosea. The activation of MtENOD11 transcription is also observed in response to purified Nod-factors and Sinorhizobium meliloti infection (Journet et al., 2001). Using this system, it has been demonstrated that the hypha from germinating spores of $G$. rosea, G. gigantea, G. margarita and $G$. intraradices separated from roots by a cellophane, polycarbonate $(0.6 \mu \mathrm{m}$ pore size $)$ or dialysis membrane (3.5 KDa molecular cut-off), produce a diffusible factor that induces the expression of MtENOD11, whereas in co-cultures with pathogenic fungi this response was not observed (Kosuta et al., 2003). Activation of the MtENOD11 promoter by the diffusible factor was also observed in M. truncatula mutants unable to form nodules and AM (dmi1, dmi2, and $d m i 3$ ), whereas the reporter was not activated by Nod-factors. These data indicate that AMF secretes specific diffusible factors, probably with less than 3.5 $\mathrm{KDa}$, which can induce the expression of an early nodulin gene in the host roots, and that its transduction pathway in not dependent on DMI.

In contrast, the expression of 11 genes involved in signal transduction, transcription and translation, with induced expression during appressorium differentiation in M. truncatula-G. mosseae interaction, has been shown to be modulated in the absence of di- 
rect contact of the roots of myc ${ }^{+}$plants with the AMF and dependent on DMI3 (Weidmann et al., 2004). These data suggest that there is an early discrimination in the perception of Myc-factors and Nod-factors, and that Myc-factor transduction may occur through distinct pathways, indicating complex signaling and transduction mechanisms. In addition, the synthesis of multiple signal molecules by AMF may also be possible. Kohki Akiyama (Osaka Prefecture University, Japan) at the "Mycorrhiza: Systems Research from Genes to Communities" held in March, 2006, in Switzerland, showed that methanol extracts of germinating G. margarita spores induce the expression of the AM inducible $L$. japonicus Cbp1 (calcium binding protein 1) promoter at the infection site in the $L$. japonicus T90B transgenic line (Akiyama, 2006), and suggested that this signal molecule is lipophilic and non-polar, and do not have the same chemical nature of the Nodfactors. He also suggested that exudates of fungal hypha contain more than one active molecule.

\section{Appressorium differentiation and root penetration}

After spore germination and hypha growth in the rhizosphere, growing hyphae differentiates into an appressorium at the root surface. The signals that trigger appressorium differentiation are not known. Synthetic surfaces do not stimulate appressorium differentiation and AMF do not form appressoria on the surface of non-mycorrhizal plants, suggesting that these fungi recognize specific cues on the roots, and nonmycorrhizal plants may not synthesize the signal molecule necessary for appressorium differentiation. Alternatively, these molecules may be synthesized in concentrations below a required threshold for the induction of appressoria differentiation (Giovannetti \& Citernesi, 1993; Giovannetti et al., 1993).

The hypothesis of the existence of specific cues on the root surface of host plants is corroborated by the fact that $G$. margarita forms appressoria on the cell wall of epidermal cells isolated from carrot roots, a host plant, but not on the cell wall of epidermal cells from sugar beet, a non-host plant (Nagahashi \& Douds, 1997). Likewise, there is no appressorium differentiation on the surface of cortical and vascular cells, suggesting that the signal for appressorium differentiation is cell specific. Considering the complexity of the process of appressorium differentiation on the surface of host cells, it is likely that there is a signaling mechanism involving a specific AMF appressorium differentiation inducing factor yet to be discovered.

\section{Intracellular accommodation}

After highly branched, infecting hyphae forms an appressorium at the root surface, penetration of the outer root tissues may take place. The intracellular growth of the AMF hyphae is accompanied by the invagination of the plant plasma membrane and synthesis of an associated matrix (Novero et al., 2002). Using an experimental system consisting of Medicago truncatula roots transformed with Agrobacterium rhizogenes infected with G. margarita, a transient migration of the epidermal cell nucleus towards the appressorium contact site, and an associated rearrangement of the cytoskeleton and endoplasmic reticulum in the plant cell has been shown to occur (Chabaud et al., 2002). This transient assembly, designated pre-penetration apparatus (PPA), defines the subsequent accommodation of the intracellular hyphae and might play a major role in the biosynthesis of the interface between fungus and plant plasma membranes (Genre et al., 2005). In a second stage, the nucleus migrates from the appressorium contact site through the epidermal cell cytoplasm directing the growth of the penetrating hyphae, and creating appropriate conditions for progressing the infection. PPA formation and transcellular nuclear migration has not been observed in infection-defective $M$. truncatula mutants (dmi2-2 and dmi3-1).

These data indicate that the host plant is actively involved in preparing the cells for the intracellular accommodation of the infecting AMF, in a process comparable to the one observed during the colonization of cortical cells by Rhizobium, where a transcellular membrane-matrix tube, named infection thread, is synthesized accompanying membrane invagination (Gage, 2004). The infection thread growth is also directed by a migrating nucleus just ahead of its growing tip. The similarities of the two processes suggest that the mechanisms controlling the intracellular accommodation of both symbionts may be analogous (Genre et al., 2005).

\section{Arbuscule development}

Simultaneously to the intercellular and/or transcellular growth of the AMF hypha, terminal hypha differentiate into arbuscules, within certain inner cortical cells. Because of its proximity to the vascular system, it has been suggested that the development of arbuscules in the inner cortical cells may be regulated by a carbon gradient (Blee \& Anderson, 1998). Even though the colonization of cortical cells is essential for arbuscule differentiation (Genre \& Bonfante, 2002), the signals that trigger the dichotomous branching of the AMF hypha to form the arbuscules remain to be identified.

Arbuscule differentiation is accompanied by several physiological changes in the plant cell, whose vacuole becomes greatly fragmented and the volume of cytoplasm and number of organelles increases 
(Bonfante \& Perotto, 1995). The nuclei of arbusculescontaining cells normally show hypertrophy and high levels of transcriptional activity (Lingua et al., 2001; Bonfante \& Perotto, 1995; Balestrini et al., 1992). Additionally, network-like plastid structures and higher number of mitochondria in arbuscule-containing cells are also observed (Fester et al., 2001). The activation of the mitochondrial tricarboxilic acid cycle and fatty acid, amino acid, and apocarotenoid biosynthesis in the plastids indicate a strong induction of the plant metabolism (Lohse et al., 2005). Rearrangement of the cytoskeleton has also been observed during the development and senescence of arbuscules (Genre \& Bonfante, 1997), as wells as in the vicinity of cells containing arbuscules (Blancaflor et al., 2001).

Harrison (2005) suggests that at least two signaling, cell autonomous and non-autonomous, events occur during arbuscule development. The cell autonomous signaling would be responsible for the activation of the expression of certain genes exclusively in cells containing arbuscules (i.e. mycorrhiza-specific phosphate transporters, a cellulose, a chitinase, and a proton ATPase). The cell non-autonomous signaling would be involved in the activation of specific genes in cells containing arbuscules and their immediate vicinity (i.e. a GST, a chitinase, a $\beta$-13endoglucanase). Another evidence for this signaling pathway is the reorganization of the microtubule cytoskeleton in cortical cells adjacent to cells containing arbuscules (Blancaflor et al., 2001). The existence of a systemic signal in AM roots-containing arbuscules has also been suggested by Lambais \& Mehdy (1998), which showed an induction in the accumulation of transcripts encoding an acidic chitinase in cells containing arbuscules and their immediate vicinity, using in situ hybridization.

Arbuscules are ephemeral structures and may last four to 10 days (Sanders et al., 1977). After this short period, the formation of septa in the arbuscule hyphae is observed and the structure collapses. During arbuscule senescence and collapsing, a localized production of reactive oxygen species is observed (Salzer et al., 1999). Arbuscule collapsing may be somehow associated with plastid metabolism, since the plastid morphology in cells containing well developed arbuscules differ significantly from that in cells containing collapsed arbuscules (Fester, 2006). After collapsing, the arbuscules are completely degraded and the plant cell resumes its normal physiology.

\section{Regulation of AM development}

A comprehensive understanding of the mechanisms controlling AM development is currently lacking. The possible roles of plant defense-related pro- teins, such as chitinases, glucanases, and enzymes involved in the metabolism of reactive oxygen species in the control of the intraradical fungal growth, under different phosphate conditions, have been investigated using enzymatic and gene expression assays (Lambais et al., 2003; Lambais \& Mehdy, 1998; 1996; 1993). It has been proposed that plant hormones may play a key role in the regulation of the intraradical fungal growth in AM (Lambais \& Mehdy, 1995). Evaluating several hormonal mutants of Micro-Tom tomato for AM development, it has been observed that an ethylene overproducer mutant showed reduced levels of intraradical AMF growth and higher levels of transcripts encoding a basic chitinase, in comparison to Micro-Tom tomato (Zsögön, 2006).

The discovery that some pea mutants unable to form symbioses with nitrogen-fixing rhizobia (nod $\left.{ }^{-}\right)$ were also unable to develop AM (myc), suggests that both symbioses share common regulatory mechanism (Hirsch \& Kapulnik, 1998). The induction of several genes, such as the early nodulins PsENOD12A, Psam5, MsENOD2, MsENOD40, MtENOD11, and leghaemoglobin VfLb29, for instance, during the development of both symbioses, corroborates this hypothesis (Albrecht et al., 1998; vanRhijn et al., 1997; Fruhling et al., 1997). The use of model legume plants such as $M$. truncatula and L. japonicus has lead to the identification of several mutants impaired in nodule as well as in AM development, and are being useful to elucidate the molecular mechanisms involved in the regulation of these symbioses (Harrison, 2005). In addition, several genes involved in the regulation of nodule and AM development have putative orthologs in A. thaliana and rice (Zhu et al., 2006). Some of these orthologs were also identified in sugarcane (Takahashi et al., 2005). The M. truncatula dmi (does not make infection) mutants and the L. japonicus mutant Ljsym2 are phenotypically similar to the first pea myc mutants, and have the infection process blocked at the stage of epidermal cell penetration, indicating that the mutated genes are essential for nodule development and AM formation (Harrison, 2005).

In legume-rhizobia interactions, bacteria produce lipochitooligosaccharide signal molecules (Nodfactors) in response to plant flavonoids (Riely et al., 2004). The Nod-factors are able to activate the expression of plant genes involved in nodule organogenesis and root hair deformation in concentrations as low as $10^{-12} \mathrm{M}$. Plant responses to Nod-factors occurs within one to 10 minutes after addition to the medium, and include rapid changes in ion fluxes and influx of $\mathrm{Ca}^{+2}$, followed by membrane depolarization and oscillations in cytoplasmic $\mathrm{Ca}^{+2}$ concentrations $\left(\mathrm{Ca}^{+2}\right.$ spiking). The current knowledge on the possible signal transduction 
pathway triggered by Nod-factors in plant cells involves a Nod-factor receptor kinase (NFR) complex (Figure 1). The NFR complex was identified in $L$. japonicus and contains two receptor-like kinases, LjNFR1 and LjNFR5, with LysM motifs in their extracellular domain (Radutoiu et al., 2003; Madsen et al., 2003). LysM motifs are involved in peptidoglycan binding and are present in two proteins known to bind chitin (Ponting et al., 1999). These proteins may be involved in binding Nod-factors, even thought no binding activity has been detected so far. Mutants $n f r 1$ and $n f r 5$ do not respond to Nod-factors, so that $\mathrm{Ca}^{+2}$ influx is not observed, but can develop functional AM (Radutoiu et al., 2003; Madsen et al., 2003), suggesting that this proteins are specifically involved in the perception of the bacterial signal.

Another gene involved in the plant response to Nod-factors is DMI2 of M. truncatula, and its ortholog SYMRK (LjsSYM2) of L. japonicus. DMI2/ $S Y M R K$ encodes transmembrane receptor-like kinases essential for the transduction of the Nod-factor (Oldroyd \& Downie, 2004). These proteins contain leucine reach repeats, normally involved in protein-protein interactions, which might also be involved in the binding of additional signal molecules. DMI2/SYMRK mutants show $\mathrm{Ca}^{+2}$ influx but not $\mathrm{Ca}^{+2}$ spiking, and do not develop AM, suggesting that these proteins act downstream of the NFR complex in the signal transduction pathway, and are specifically involved in the recognition of Myc-factors. Whether the NFR complex interacts directly with DMI2/SYMRK or through an intermediate molecule during the transduction of the Nod-factor has to be determined, but certainly NFR is not essential for AM development.

The characterization of additional plant mutants has unveiled two other genes, DMI1 and DMI3, required for both nodule and AM development. DMI1 has been shown to act downstream of DMI2/SYMRK and upstream of DMI3, and is a putative cation channel possibly involved in $\mathrm{Ca}^{+2}$ spiking (Oldroyd \&

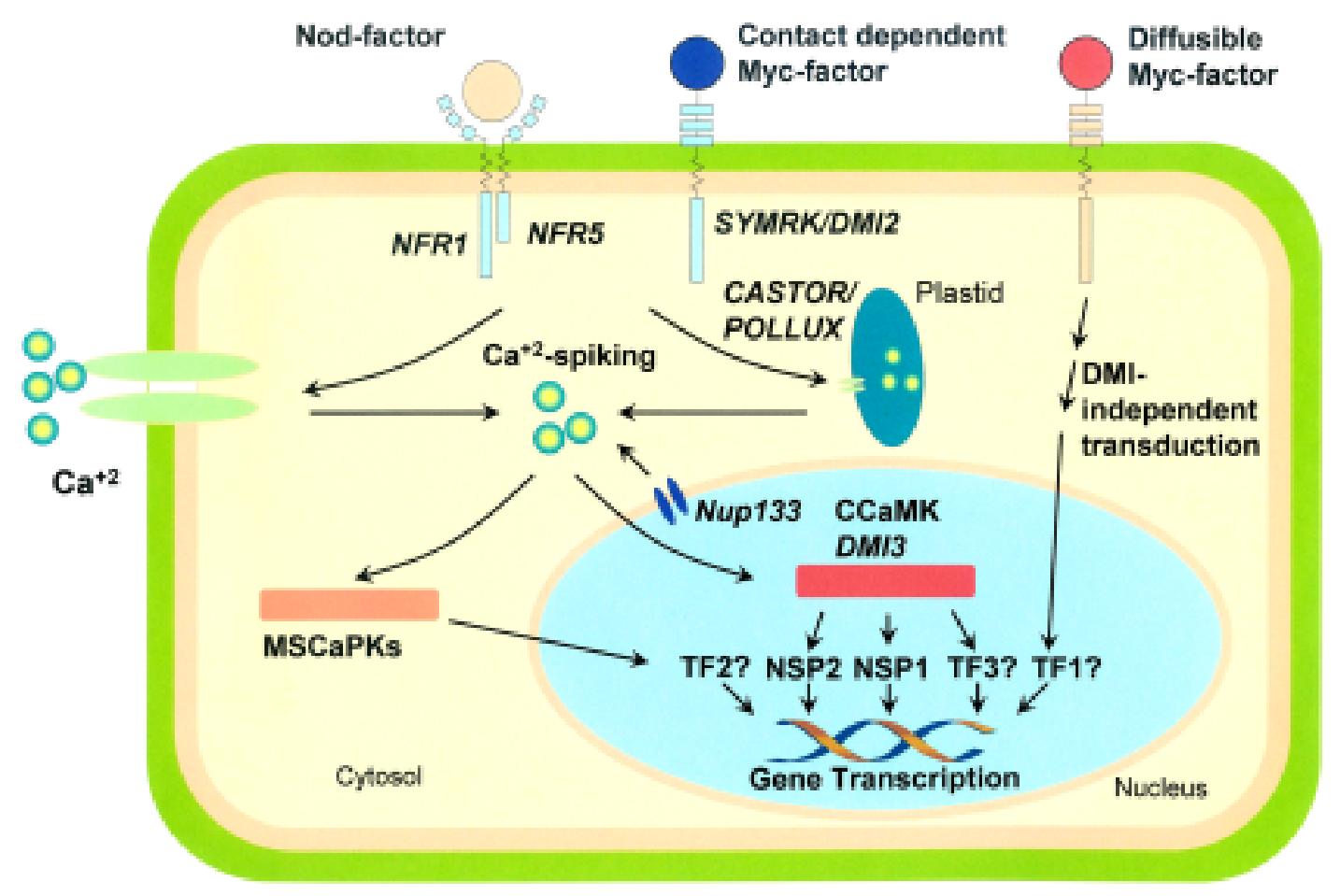

Figure 1 - Possible signal transduction pathways triggered by Nod- and Myc-factors in legume root cells. Nod and contact-dependent Myc factors are recognized at the cell surface by receptor-like kinases (NFR and SYMRK/DMI2). Protein hosphorylation events may lead to the activation of $\mathrm{Ca}^{+2}$ influxes into the cytoplasm and $\mathrm{Ca}^{+2}$ spiking in the perinuclear region, mediated by CASTOR/POLLUX and Nup133 gene products. A nuclear calcium/calmodulin-dependent protein kinase (CCaMK/DMI3) is activated, which in turn phosphorylates transcription factors specifically involved in nodule differentiation (NSP1 and NSP2) or AM development (TF3). Cytoplasmic $\mathrm{Ca}^{+2}$ oscillation signatures may also activate mycorrhiza-specific calcium-dependent protein kinases (MSCaPKs), which would activate specific transcription factors (TF2) involved in the regulation of gene expression in AM. In addition, a not yet known DMI-independent transduction pathway may also be triggered upon recognition of a diffusible Myc-fator, resulting in the possible activation of a mycorrhiza-specific transcription factor (TF1) also involved in the regulation of genes essential for AM development. 
Downie, 2004). However, the identification of two proteins in L. japonicus, CASTOR and POLLUX, homologous to DMI1 and showing plastid localization, suggest that these cation channels are not likely the channels responsible for $\mathrm{Ca}^{+2}$ spiking (Imaizumi-Anraku et al., 2005). Though, whether or not these putative channels contribute to the $\mathrm{Ca}^{+2}$ spiking remains to be determined. Whereas $\mathrm{Ca}^{+2}$ spiking in the proximity of the nuclear membrane is essential for the activation of genes involved in nodule morphogenesis, the occurrence of $\mathrm{Ca}^{+2}$ spiking has never been shown to occur in AM. However, the fact that the L. japonicus Nup133 gene, encoding a nucleoporin localized in the nuclear envelope of root cells, is necessary for $\mathrm{Ca}^{+2}$ spiking and that nup133 mutants do no show root colonization by AMF, suggest that $\mathrm{Ca}^{+2}$ spiking is also essential for AM development (Kanamori et al., 2006).

The analyses of $M$. truncatula mutants showing $\mathrm{Ca}^{+2}$ spiking but unable to activate the expression of early nodulin genes, resulted in the identification of the DMI3 gene, which encodes a chimeric calcium/ calmodulin-dependent protein kinase (CCaMK) with nuclear localization (Levy et al., 2004). Apparently, downstream of DMI3 the transduction pathways for Nod- and Myc-factors are divergent (Figure 1). In response to Nod-factors, two putative transcription factors of the GRAS family, NSP1 and NSP2, are possibly activated by phosphorylayion mediated by DMI3CCaMK, since mutants impaired in nps show $\mathrm{Ca}^{+2}$ spiking but are not able to express early nodulin genes (Catoira et al., 2000). In AM, the targets of DMI3CCaMK are not yet known, but certainly nsp1 and nsp2 are not involved, since mutants for these genes still develop AM (Udvardi \& Scheible, 2005).

In contrast, the response of M. truncatula dmi1, dmi2 and dmi3 mutants to Nod-factors and a diffusible Myc-factor, evaluated using MtENOD11-gusA as a reporter system, indicates that $D M I$ gene products are not required for Myc-fator induced expression of MtENOD11 as they are for the Nod-factor responses (Kosuta et al., 2003). These data suggest that at least two Myc-factors may be synthesized by AMF, one factor produced at the contact point between the symbionts and transduced via the DMI-dependent pathway, and a diffusible, contact-independent factor transduced through a DMI-independent pathway (Figure 1). Analyses of changes in the root transcriptome during AM development in wild-type $L$. japonicus and mutants affected in common SYM genes, provide additional evidence for the existence of a signal perception/transduction pathway independent of DMI (Kistner et al., 2005).

Several questions remain to be answered in order to completely understand the signal transduction pathways leading to AM formation and certainly we will benefit from the isolation and characterization of the Myc-factor, and the identification of new mutants impaired in different stages of AM development. Symbioses defective mutant populations have been generated using different approaches (chemical, T-DNA insertion and fast-neutrons mutagenesis, for instance) and identification of the alleles involved in phenotypic variation of the mutants is underway in several laboratories. Using diallelic crosses of $L$. japonicus symbioses mutant lines, seven common SYM genes required for both rhiozobial and mycorrhizal symbioses have been identified (Kistner et al., 2005). However, there are more than 400 symbiotic $L$. janonicus mutants available (Sandal et al., 2006) and using diallelic crossing would take a long time to identify SYM genes. To overcome this limitation, different tools are being developed, such as Targeting Induced Local Lesions IN Genomes (TILLING) (McCallum et al., 2000) and Recombinant Inbred Lines (RILs) (Sandal et al., 2006), which will help to identify the genes involved specifically in AM regulation.

\section{CONCLUDING REMARKS}

The use of genomics and functional genomics of model plants has led to significant advances in the understanding of the mechanisms controlling AM development. The identification of a $\mathrm{BF}$ produced by plants and the perspective of the identification of signal molecules synthesized by AMF bring new insights on the signaling and signal transduction pathways necessary for AM formation. Possibly, at least two fungal signal molecules might be synthesized during the pre-symbiotic and early stages of the infection process, which are recognized via receptor-like kinases and transduced via CCaMK, as in legumerhizobia symbioses. Apparently, the signature of $\mathrm{Ca}^{+2}$ oscillations in the cytoplasm is the one of the events discriminating rhizobia from AMF signals, even though there is an alternative transduction pathway still to be detailed. The development of new tools for cloning genes differentially expressed in AM, screening mutants of model plants and functional genomics will certainly abbreviate the time necessary for the large scale application of AM in agriculture.

\section{ACKNOWLEDGEMENTS}

The author is supported by CNPq (Brasília, Brazil) and FAPESP (São Paulo, Brazil). Thanks to José Oswaldo Siqueira (UFLA, Lavras, Brazil) and Ricardo Antunes Azevedo (ESALQ, Piracicaba, Brazil) for the critical review of the manuscript. 


\section{REFERENCES}

AKIYAMA, K. Chemical identification of plant and fungal signaling molecules in arbuscular mycorrhizal symbiosis. In: MYCORRHIZA: SYSTEMS RESEARCH FROM GENES TO COMMUNITIES, Ascona, 2006. Book of abstracts. Ascona: Swiss Federal Institute of Technology Zurich, 2006. p.24.

AKIYAMA, K.; MATSUZAKI, K.; HAYASHI, H. Plant sesquiterpenes induce hyphal branching in arbuscular mycorrhizal fungi. Nature, v.435, p.824-827, 2005

ALBRECHT, C.; GEURTS, R.; LAPEYRIE, F.; BISSELING, T. Endomycorrhizae and rhizobial Nod factors both require SYM8 to induce the expression of the early nodulin genes PSENOD5 and PsENOD12A. Plant Journal, v.15, p.605-614, 1998.

BALESTRINI, R.; BERTA, G.; BONFANTE, P. The plant nucleus in mycorrhizal roots - positional and structural modifications. Biology of the Cell, v.75, p.235-243, 1992.

BECARD, G.; TAYLOR, L.P.; DOUDS, D.D.; PFEFFER, P.E.; DONER, L.W. Flavonoids are not necessary plant signal compounds in arbuscular mycorrhizal symbioses. Molecular Plant-Microbe Interactions, v.8, p.252-258, 1995.

BLANCAFLOR, E.B.; ZHAO, L.M.; HARRISON, M.J. Microtubule organization in root cells of Medicago truncatula during development of an arbuscular mycorrhizal symbiosis with Glomus versiforme. Protoplasma, v.217, p.154-165, 2001.

BLEE, K.A.; ANDERSON, A.J. Regulation of arbuscule formation by carbon in the plant. Plant Journal, v.16, p.523-530, 1998.

BONFANTE, P.; PEROTTO, S. Strategies of arbuscular mycorrhizal fungi when infecting host plants. New Phytologist, v.130, p.3-21, 1995.

BUEE, M.; ROSSIGNOL, M.; JAUNEAU, A.; RANJEVA, R.; BECARD, G. The pre-symbiotic growth of arbuscular mycorrhizal fungi is induced by a branching factor partially purified from plant root exudates. Molecular Plant-Microbe Interactions, v.13, p.693-698, 2000.

CATOIRA, R.; GALERA, C.; DE BILLY, F.; PENMETSA, R.V.; JOURNET, E.P.; MAILLET, F.; ROSENBERG, C.; COOK, D.; GOUGH, C.; DENARIE, J. Four genes of Medicago truncatula controlling components of a nod factor transduction pathway. Plant Cell, v.12, p.1647-1665, 2000.

CHABAUD, M.; VENARD, C.; DEFAUX-PETRAS, A.; BECARD, G.; BARKER, D.G. Targeted inoculation of Medicago truncatula in vitro root cultures reveals MtENOD11 expression during early stages of infection by arbuscular mycorrhizal fungi. New Phytologist, v.156, p.265-273, 2002.

FESTER, T. Plastid metabolism and proliferation in arbuscular mycorrhizal roots. In: MYCORRHIZA: SYSTEMS RESEARCH FROM GENES TO COMMUNITIES, Ascona, 2006. Book of abstracts. Ascona: Swiss Federal Institute of Technology Zurich, 2006. p.36.

FESTER, T.; STRACK, D.; HAUSE, B. Reorganization of tobacco root plastids during arbuscule development. Planta, v.213, p.864-868, 2001.

FRUHLING, M.; ROUSSEL, H.; GIANINAZZIPEARSON, V.; PUHLER, A.; PERLICK, A.M. The Vicia faba leghemoglobin gene VfLb29 is induced in root nodules and in roots colonized by the arbuscular mycorrhizal fungus Glomus fasciculatum. Molecular Plant-Microbe Interactions, v.10, p.124-131, 1997.

GAGE, D.J. Infection and invasion of roots by symbiotic, nitrogen-fixing rhizobia during nodulation of temperate legumes. Microbiology and Molecular Biology Reviews, v.68, p.280-300, 2004.

GENRE, A.; BONFANTE, P. A mycorrhizal fungus changes microtubule orientation in tobacco root cells. Protoplasma, v.199, p.30-38, 1997.

GENRE, A.; BONFANTE, P. Epidermal cells of a symbiosis-defective mutant of Lotus japonicus show altered cytoskeleton organisation in the presence of a mycorrhizal fungus. Protoplasma, v.219, p.43-50, 2002.

GENRE, A.; CHABAUD, M.; TIMMERS, T.; BONFANTE, P.; BARKER, D.G. Arbuscular mycorrhizal fungi elicit a novel intracellular apparatus in Medicago truncatula root epidermal cells before infection. Plant Cell, v.17, p.3489-3499, 2005.
GIOVANNETTI, M.; CITERNESI, A.S. Time-course of appressorium formation on host plants by arbuscular mycorrhizal fungi. Mycological Research, v.97, p.1140-1142, 1993.

GIOVANNETTI, M.; SBRANA, C.; LOGI, C. Early processes involved in host recognition by arbuscular mycorrhizal fungi. New Phytologist, v.127, p.703-709, 1994.

GIOVANNETTI, M.; AVIO, L.; SBRANA, C.; CITERNESI, A.S. Factors affecting appressorium development in the vesicular arbuscular mycorrhizal fungus Glomus mosseae (Nicol. and Gerd.) Gerd. and Trappe. New Phytologist, v.123, p.115-122, 1993.

GIOVANNETTI, M.; SBRANA, C.; CITERNESI, A.S.; AVIO, L. Analysis of factors involved in fungal recognition responses to host derived signals by arbuscular mycorrhizal fungi. New Phytologist, v.133, p.65-71, 1996.

HARRISON, M.J. Signaling in the arbuscular mycorrhizal symbiosis. Annual Review of Microbiology, v.59, p.19-42, 2005.

HIRSCH, A.M.; KAPULNIK, Y. Signal transduction pathways in mycorrhizal associations: Comparisons with the Rhizobium-legume symbiosis. Fungal Genetics and Biology, v.23, p.205-212, 1998.

HUMPHREY, A.J.; BEALE, M.H. Strigol: Biogenesis and physiological activity. Phytochemistry, v.67, p.636-640, 2006.

IMAIZUMI-ANRAKU, H.; TAKEDA, N.; CHARPENTIER, M. et al. Plastid proteins crucial for symbiotic fungal and bacterial entry into plant roots. Nature, v.433, p.527-531, 2005.

JOURNET, E.P.; EL GACHTOULI, N.; VERNOUD, V.; DE BILLY, F.; PICHON, M.; DEDIEU, A.; ARNOULD, C.; MORANDI, D.; BARKER, D.G.; GIANINAZZI-PEARSON, V. Medicago truncatula ENOD11: A novel RPRP-encoding early nodulin gene expressed during mycorrhization in arbuscule-containing cells. Molecular Plant-Microbe Interactions, v.14, p.737-748, 2001.

KANAMORI, N.; MADSEN, L.H.; RADUTOIU, S.et al. A nucleoporin is required for induction of $\mathrm{Ca}^{2+}$ spiking in legume nodule development and essential for rhizobial and fungal symbiosis. Proceedings of the National Academy of Sciences of the USA v.103, p.359-364, 2006.

KAPE, R.; WEX, K.; PARNISKE, M.; GORGE, E.; WETZEL, A.; WERNER, D. Legume root metabolites and VA-mycorrhiza development. Journal of Plant Physiology, v.141, p.54-60, 1993.

KISTNER, C.; WINZER, T.; PITZSCHKE, A.; MULDER, L.; SATO, S.; KANEKO, T.; TABATA, S.; SANDAL, N.; STOUGAARD, J.; WEBB, K.J.; SZCZYGLOWSKI, K.; PARNISKE, M. Seven Lotus japonicus genes required for transcriptional reprogramming of the root during fungal and bacterial symbiosis. Plant Cell, v.17, p.22172229, 2005.

KOSUTA, S.; CHABAUD, M.; LOUGNON, G.; GOUGH, C.; DENARIE, J.; BARKER, D.G.; BECARD, G. A diffusible factor from arbuscular mycorrhizal fungi induces symbiosis-specific MtENOD11 expression in roots of Medicago truncatula. Plant Physiology, v.131, p.952-962, 2003.

LAMBAIS, M.R.; MEHDY, M.C. Suppression of endochitinase, $\beta-1,3-$ endoglucanase, and chalcone isomerase expression in bean vesiculararbuscular mycorrhizal roots under different soil phosphate conditions. Molecular Plant-Microbe Interactions, v.6, p.75-83, 1993.

LAMBAIS, M.R.; MEHDY, M.C. Differential expression of defenserelated genes in arbuscular mycorrhiza. Canadian Journal of Botany, v.73, p.S533-S540, 1995.

LAMBAIS, M.R.; MEHDY, M.C. Soybean roots infected by Glomus intraradices strains differing in infectivity exhibit differential chitinase and $\beta$-1,3-glucanase expression. New Phytologist, v.134, p.531-538, 1996.

LAMBAIS, M.R.; MEHDY, M.C. Spatial distribution of chitinases and $\beta$-1,3-glucanase transcripts in bean arbuscular mycorrhizal roots under low and high soil phosphate conditions. New Phytologist, v.140, p.33-42, 1998.

LAMBAIS, M.R.; RIOS-RUIZ, W.F.; ANDRADE, R.M. Antioxidant responses in bean (Phaseolus vulgaris) roots colonized by arbuscular mycorrhizal fungi. New Phytologist, v.160, p.421-428, 2003. 
LENDZEMO, V.W.; KUYPER, T.W.; KROPFF, M.J.; VAN AST, A. Field inoculation with arbuscular mycorrhizal fungi reduces Striga hermonthica performance on cereal crops and has the potential to contribute to integrated Striga management. Field Crops Research, v.91, p.51-61, 2005.

LEVY, J.; BRES, C.; GEURTS, R.; CHALHOUB, B.; KULIKOVA, O.; DUC, G.; JOURNET, E.P.; ANE, J.M.; LAUBER, E.; BISSELING, T.; DENARIE, J.; ROSENBERG, C.; DEBELLE, F. A putative $\mathrm{Ca}^{2+}$ and calmodulin-dependent protein kinase required for bacterial and fungal symbioses. Science, v.303, p.1361-1364, 2004.

LINGUA, G; FUSCONI, A.; BERTA, G. The nucleus of differentiated root plant cells: modifications induced by arbuscular mycorrhizal fungi. European Journal of Histochemistry, v.45, p.9-20, 2001.

LOHSE, S.; SCHLIEMANN, W.; AMMER, C.; KOPKA, J.; STRACK, D.; FESTER, T. Organization and metabolism of plastids and mitochondria in arbuscular mycorrhizal roots of Medicago truncatula. Plant Physiology, v.139, p.329-340, 2005.

MADSEN, E.B.; MADSEN, L.H.; RADUTOIU, S.; OLBRYT, M.; RAKWALSKA, M.; SZCZYGLOWSKI, K.; SATO, S.; KANEKO, T.; TABATA, S.; SANDAL, N.; STOUGAARD, J. A receptor kinase gene of the LysM type is involved in legume perception of rhizobial signals. Nature, v.425, p.637-640, 2003.

MATUSOVA, R.; RANI, K.; VERSTAPPEN, F.W.A.; FRANSSEN, M.C.R.; BEALE, M.H.; BOUWMEESTER, H.J. The strigolactone germination stimulants of the plant-parasitic Striga and Orobanche spp. are derived from the carotenoid pathway. Plant Physiology, v.139, p.920-934, 2005.

MCCALLUM, C.M.; COMAI, L.; GREENE, E.A.; HENIKOFF, S. Targeting induced local lesions in genomes (TILLING) for plant functional genomics. Plant Physiology, v.123, p.439-442, 2000.

MOSSE, B. Advances in study of vesicular-arbuscular mycorrhiza. Annual Review of Phytopathology, v.11, p.171-196, 1973.

NAGAHASHI, G.; DOUDS, D.D. Appressorium formation by AM fungi on isolated cell walls of carrot roots. New Phytologist, v.136, p.299304, 1997.

NAGAHASHI, G.; DOUDS, D.D. Rapid and sensitive bioassay to study signals between root exudates and arbuscular mycorrhizal fungi. Biotechnology Techniques, v.13, p.893-897, 1999.

NAGAHASHI, G.; DOUDS, D.D. Partial separation of root exudate components and their effects upon the growth of germinated spores of AM fungi. Mycological Research, v.104, p.1453-1464, 2000.

NAIR, M.G.; SAFIR, G.R.; SIQUEIRA, J.O. Isolation and identification of vesicular-arbuscular mycorrhiza-stimulatory compounds from clover (Trifolium repens) roots. Applied and Environmental Microbiology, v.57, p.434-439, 1991.

NOVERO, M.; FACCIO, A.; GENRE, A.; STOUGAARD, J.; WEBB, K.J.; MULDER, L.; PARNISKE, M.; BONFANTE, P. Dual requirement of the LjSym4 gene for mycorrhizal development in epidermal and cortical cells of Lotus japonicus roots. New Phytologist, v.154, p.741-749, 2002.

OLDROYD, G.E.D.; DOWNIE, J.A. Calcium, kinases and nodulation signalling in legumes. Nature Reviews Molecular Cell Biology, v.5, p.566-576, 2004.

PONTING, C.P.; ARAVIND, L.; SCHULTZ, J.; BORK, P.; KOONIN, E.V. Eukaryotic signalling domain homologues in Archaea and Bacteria. Ancient ancestry and horizontal gene transfer. Journal of Molecular Biology, v.289, p.729-745, 1999.

RADUTOIU, S.; MADSEN, L.H.; MADSEN, E.B.; FELLE, H.H.; UMEHARA, Y.; GRONLUND, M.; SATO, S.; NAKAMURA, Y.; TABATA, S.; SANDAL, N.; STOUGAARD, J. Plant recognition of symbiotic bacteria requires two LysM receptor-like kinases. Nature, v.425, p.585-592, 2003.
RIELY, B.K.; ANE, J.M.; PENMETSA, R.V.; COOK, D.R. Genetic and genomic analysis in model legumes bring Nod-factor signaling to center stage. Current Opinion in Plant Biology, v.7, p.408-413, 2004.

SALZER, P.; CORBIERE, H.; BOLLER, T. Hydrogen peroxide accumulation in Medicago truncatula roots colonized by the arbuscular mycorrhiza-forming fungus Glomus intraradices. Planta, v.208, p.319-325, 1999.

SANDAL, N.; PETERSEN, T.R.; MURRAY, J.et al. Genetics of symbiosis in Lotus japonicus: Recombinant inbred lines, comparative genetic maps, and map position of 35 symbiotic loci. Molecular Plant-Microbe Interactions, v.19, p.80-91, 2006.

SANDERS, F.E.; TINKER, P.B.; BLACK, R.L.B.; PALMERLEY, S.M. Development of endomycorrhizal root systems .1. Spread of infection and growth-promoting effects with 4 species of vesicular-arbuscular endophyte. New Phytologist, v.78, p.257-268, 1977.

SIQUEIRA, J.O.; NAIR, M.G.; HAMMERSCHMIDT, R.; SAFIR, G.R. Significance of phenolic-compounds in plant-soil-microbial systems. Critical Reviews in Plant Sciences, v.10, p.63-121, 1991a.

SIQUEIRA, J.O.; SAFIR, G.R.; NAIR, M.G. Stimulation of vesiculararbuscular mycorrhiza formation and growth of white clover by flavonoid compounds. New Phytologist, v.118, p.87-93, 1991b.

SIQUEIRA, J.O.; SYLVIA, D.M.; GIBSON, J.; HUBBELL, D.H. SPORES, Germination, and germ tubes of vesicular-arbuscular mycorrhizal fungi. Canadian Journal of Microbiology, v.31, p.965972, 1985.

TAKAHASHI, D.; KIRIACHEK, S.G.; HARDOIM, P.R.; LAMBAIS, M.R. Genes essenciais para o estabelecimento de simbioses em leguminosas também são encontrados em cana-de-açúcar. In: XXIII CONGRESSO BRASILEIRO DE MICROBIOLOGIA, Santos, 2005. Proceedings. Santos: Mendes Convention Center, 2005. p.294.

UDVARDI, M.K.; SCHEIBLE, W.R. GRAS genes and the symbiotic Green Revolution. Science, v.308, p.1749-1750, 2005.

Van RHIJN, P.; FANG, Y.; GALILI, S.; SHAUL, O.; ATZMON, N.; WININGER, S.; ESHED, Y.; LUM, M.; LI, Y.; TO, V.; FUJISHIGE, N.; KAPULNIK, Y.; HIRSCH, A.M. Expression of early nodulin genes in alfalfa mycorrhizae indicates that signal transduction pathways used in forming arbuscular mycorrhizae and Rhizobiuminduced nodules may be conserved. Proceedings of the National Academy of Sciences of the USA, v.94, p.5467-5472, 1997.

WEIDMANN, S.; SANCHEZ, L.; DESCOMBIN, J.; CHATAGNIER, O.; GIANINAZZI, S.; GIANINAZZI-PEARSON, V. Fungal elicitation of signal transduction-related plant genes precedes mycorrhiza establishment and requires the dmi3 gene in Medicago truncatula. Molecular Plant-Microbe Interactions, v.17, p.13851393, 2004.

WESTWOOD, J.H. Characterization of the Orobanche-Arabidopsis system for studying parasite-host interactions. Weed Science, v.48, p.742-748, 2000.

YONEYAMA, K.; TAKEUCHI, Y.; YOKOTA, T. Production of clover broomrape seed germination stimulants by red clover root requires nitrate but is inhibited by phosphate and ammonium. Physiologia Plantarum, v.112, p.25-30, 2001.

ZHU, H.; RIELY, B.K.; BURNS, N.J.; ANÉ, J.-M. Tracing non-legume orthologs of legume genes required for nodulation and arbuscular mycorrhizal symbioses. Genetics, v.172, p.2491-2499, 2006.

ZSÖGÖN, A. Utilização do cultivar miniatura de tomateiro (Micro-Tom) como modelo para o estudo da sinalização planta-micorriza. Piracicaba:USP/ESALQ, 2006. 51p. (Dissertação - Mestrado).

Received January 09, 2006

Accepted July 05, 2006 